\section{International Scientific Journal Theoretical \& Applied Science \\ p-ISSN: $2308-4944$ (print) \\ e-ISSN: 2409-0085 (online) \\ Year: 2015 \\ Issue: $01 \quad$ Volume: 21 \\ Published: 30.01 .2015 \\ http://www.T-Science.org}

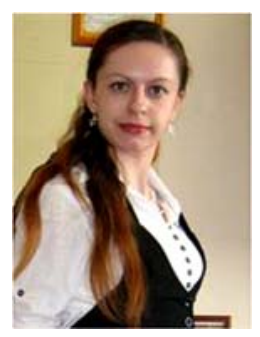

Elena Yurievna Malushko Candidate of Education Sciences,

Senior teacher of the

Department of professional foreign language communication, Volgograd state university, Russia malushko_elena@mail.ru

SECTION 21. Pedagogy. Psychology. Innovations in the field of education.

\title{
METHODOLOGICAL PODCASTS AS A WAY FOR DEVELOPING THE PRE-SERVICE TEACHERS' PROFESSIONAL COMPETENCE AND SKILLS
}

\begin{abstract}
The article conveys the aspects of integrating audio- and videopodcasts into teaching practice and their role in developing pre-service teachers' professional competence. Most pre-service teachers are often incapable to hold their own independent practice and to apply gained theoretical knowledge to practice. Such problems are solved with the help of methodological podcasts containing the authentic learning-teaching environment and methodological recommendations on teaching practice made by in-service teachers, experienced educators and educational experts. Use of casts helps to form professional competence and self-efficacy of the preservice teachers.

Key words: foreign language teaching, cyberspace technologies, Internet resource, authentic podcast, preservice teachers, self-efficacy, professional competence.

Language: English

Citation: Malushko EY (2015) METHODOLOGICAL PODCASTS AS A WAY FOR DEVELOPING THE PRE-SERVICE TEACHERS' PROFESSIONAL COMPETENCE AND SKILLS. ISJ Theoretical \& Applied Science 01 (21): 173-177. doi: http://dx.doi.org/10.15863/TAS.2015.01.21.29
\end{abstract}

\section{Introduction.}

Contemporary classes at any educational institution cannot be imagined without multimedia support which allows teachers to use authentic videoand audiofiles in classroom background and brings the process of acquiring subject knowledge closer to a process of real-time communication. It's mostly important in a language class. Still long before the appearance of the Internet experts discovered the dependence between the method of acquiring knowledge and the ability to recollect acquired data after some period of time. If the material was represented only orally, a person could remember about one forth of it; if the information was represented visually - about one third. The use of the combined source (visual and auditive) doubles the teaching effectiveness and active participation of students in the learning process triples the result. So multimedia denotes the joining of several ways of presenting the information - text, stationary images, moving pictures - improving teaching methods. Nowadays multimedia is used for imitating real situations of communication, which can happen during the professional activities of the students [5].
The aim of the work is to make the review and the detailed analysis of the podcasting services aiming at training pre-service teachers or even specialists having independent practice.

The object and methodology of research.

To achieve this goal, we have identified the following criteria: the level of student's activity, type of communication media, its authenticity and positive effect on learning process. The objects of the research were the useful and effective teachers' training podcasts $[3,4,10]$.

The results of the research and their discussion.

Modern educational system splitting up into two stages (baccalaureate and magistrate) needs constant improvement to meet international professional standards to graduates' qualification. Important part of magistrate studies (at least sixty \%) falls on self-development and includes not only the preparation for classes, but also fulfilling a project, applying for a conference, solving professional cases. This sort of self-teaching is applicable to master degree students as they have already developed necessary skills during their undergraduate studying. The same happens to many core and supplementary 
subjects such as mathematics, language, literature, and other sciences. Language and literature teaching practice shows that all language aspects such as speaking, writing, listening, reading and translating are simultaneously involved into the learning process [2]. One of the most difficult aspects in learning is undoubtedly listening as we have no visual support and a lot of disturbing factors like noise background, different intonation, speech assimilation and so on. Listening difficulties become more obvious when teaching professional aspects in the foreign language. We know that universities and other schools can have students that had a course of aiming language as a second language or didn't ever study it at all [7]. So their language competence lowers their ability to acquire the material and makes their teaching practice potentially impossible.

To relieve listening process we can appeal the new teaching and learning media and techniques such as non-linear presenting, interactive case solving, podcasting, web questing, project preparing and etc. Modern ICTs present universal approach to information and are able to interactively combine text, graphics, sounds and programming. ICT has greatly contributed to the educational system extension. We can distinguish seven main aspects influenced most by ICT in learning: extending the potential of integrated theory and practice and the use of different educational models, planning and preparing for teaching or professional practice, analyzing the real process of teaching-learning and solving real-time pedagogical situations, forming and developing necessary language communicative and professional competences, increasing the level of evaluation and reflection via observation and analysis of your own actions and actions of other teachers, reducing the distance.

One of the promising tools for professional competence development is podcasting which is defined as a process of creating, browsing and spreading podcasts through the web. Podcasts can be presented as an audio/video file having the MP3/OGG/MP4/FLV format and spreading freely through the web. Using podcasts for teaching different language aspects and particularly listening gained such a popularity among language teachers and language learners because of being contemporary, authentic, functional, rich in content, freely distributing, conveying different aspects of the world life and science, quick updateable, overtime available, motivating and case oriented. All these let us think of podcasts as sufficient tools for teaching and learning at any educational level. At the master's level this educational tool is winning its population and teacher's trust too.

The pedagogy of podcasts (podogogy) caused the emergence of teaching in the podosphere which is described as a combination of all podcasts published on podcast-terminals and podcasters creating, publishing and managing their podcasts in the web. We can find a great source of podcastterminals providing us with the access to most useful and authentic podcasts like http://itunes.apple.com/ru/podcast/teacher2.0/id270721435;

http://www.apple.com/education/itunes-

u/?ref=http://itunes.com; $\quad$ http://www.magazindeutschland.de;

http://www.bbc.co.uk/worldservice/learningenglish; cyberproofs.org; http://www.mirpod.com/podcastplayer.php?2512/Learning-Teaching-and-

Assessment-in-Higher-Education\&lang=en;

http://www.spiegel.de;

http://www.deutschland.de/bildung.html;

http://www.youtube.com/watch? $v=x r J e j r r 3 v G Y$.

Such sites store not only learning materials but also teachers' tips for using them in class or for selfdevelopment and video fragments of professional or teaching interaction in class which students can watch, analyze and assess. This also greatly contributes to self-assessment helping in its turn to form the students' self-efficacy.

One of the sites aiming at teachers is bbc.co.uk having the special section "For teachers" http://www.bbc.co.uk/worldservice/learningenglish/t each (figure - 1) implying teachers' plans, designs, students sheets, exercises examples and supportive materials helping people to engage this everything into class. There are also advisory tips recommending particular forms of collaboration, explaining the proper order of fulfilling tasks, establishing teachers' and media roles in the educational process and students' minds. Materials are oriented toward the authentic teachers and those who teach English as a foreign language. Methodical resources of iTunes and BBC.CO.UK are attended by more than 13 million users a year that proves the necessity of having such kind of online sites for teachers. 


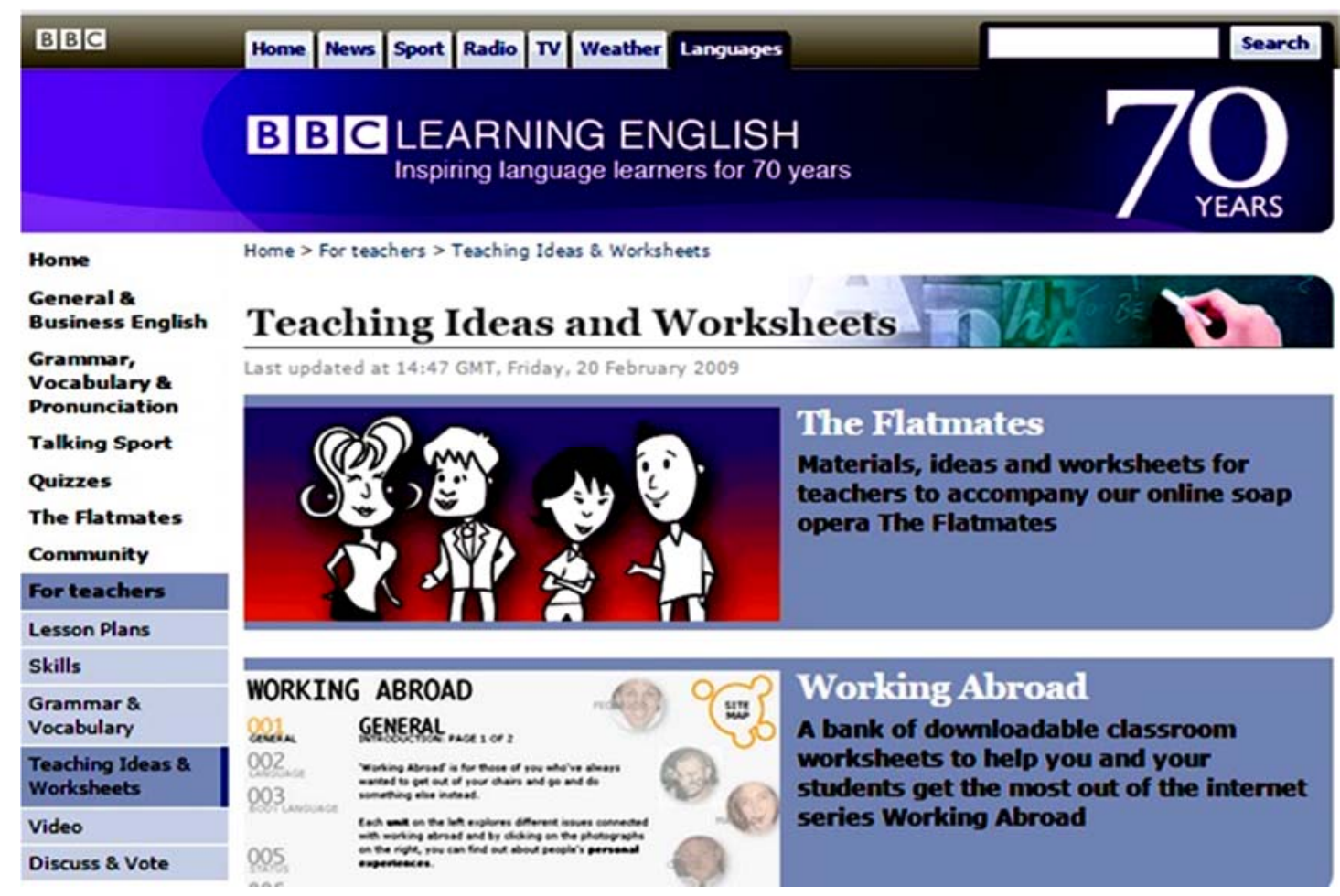

Figure 1 - The section For teachers from bbc.co.uk.

One more positive argument for podcasting is that a lot of experiences teachers and experts start podcasting their master-classes and teachers training programs

like

http://www.youtube.com/watch? $v=x r J e j r r 3 v G Y$

(figure - 2) which is provided by IH London's Teacher Training department, the largest CELTA training centre in the world having over 50 years of experience in language teaching and teacher training.
This program offers its listeners to hear about the experiences, to train teaching English as a foreign language, to find out what it's like to be in the classroom and about the challenges of training to teach English as well as how rewarding it can be. This innovative Online Training program is designed for teachers who are non-native English speakers to update their skills.

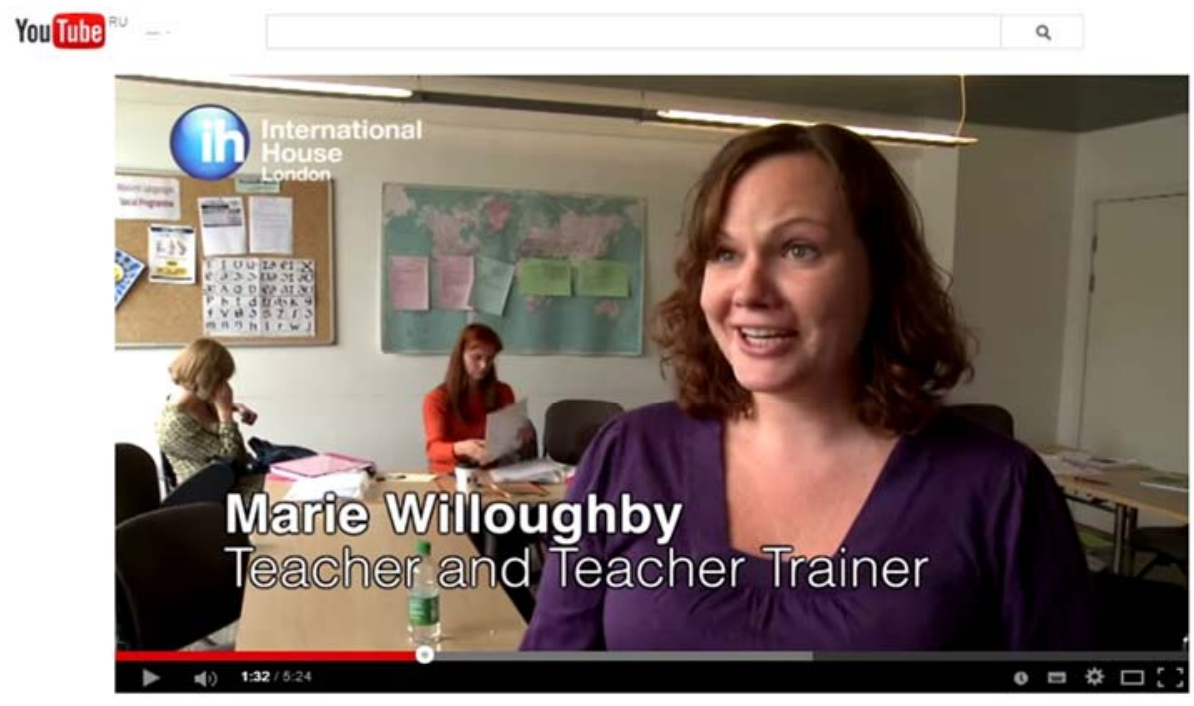

Teacher Training in London - Teach English as a Foreign Language at IH London П International House London

Figure 2 - The example podcast by CELTA training centre. 
There are also a variety of useful materials for pre-service teachers and those who are willing to develop their teaching qualification. These media help to train pre-service teachers for their future job involving experts' experience and practice, unpredictable possible class situations which teachers sometimes have to cope with, tips on class management, cooperation, creativity, intuition and assessment. It's for methodological podcasts to fill the practice gap into the theoretical preparation of pre-service teachers getting their master's degree. Usually teachers get this valuable teaching experience while facing practical problems and making their own management mistakes. As for student-teachers still having no extended practice podcasts can serve as a powerful tool to increase their teaching level before turning to independent practice. Thus we notice that standard single-way teaching prescribed by the ordinary curricular gradually turns into the interactive model though it is accompanied by increasing share of unsupervised work at the expense of classes. In other words methodological podcasts allow student-teachers get the consultation of experienced teachers, attend the teachers training seminar or master-class in the realtime mode, transfer to the real-class circumstances with the time lag (time-delayed) without leaving the classroom or home and without tearing yourself away from the computer.

One of the most important advantages of audioand videocasts (podcasts) in the teaching sphere is the emerging students' ability to predict the results of authentic classroom situations. These materials can be used as positive examples, recommended practices of teaching. Though there are podcasts containing negative teaching experience which is also valuable for student-teachers and allows them to predict all possible outcomes of educational situations and to avoid the negative ones. Thus including the training podcasts into the teaching process contributes to the developing students' reflection and the skills of evaluating the classroom situations.

To compare with direct observation videocasting has a bit more advantages:

videocasts are steady recordings available for re-watching at any time, subject to collecting and editing by the relevant programs (hypermedia programs), unbound by time and room as there is no obvious necessity to stay in the particular place and at a particular time for observation [5, p. 187-193];

following Miriam Sherin who explores the process of engaging such podcasts in teaching, we can notice the parallel development of the professional foreign language competences $[9$, p. 1521]. Thus video podcasts allow to analyze the educational process and apply the theoretical knowledge to the practical situations of teaching foreign languages;

new and lite digital form of podcasts allows to reflect specific methodological moments. N. Seago points that videocasts are able to embrace all complexity of the teaching-learning process and allow to extract the necessary content so that the observer can concentrate on the particular situational fragment [8, p. 260-261].

This way we can present the made comparison in an obvious form of a table attracting the most important advantages of each approach. The table 1 gives only a short overview of the spent analysis but it's enough to form a certain idea of using podcasting media for teaching students and developing teachers' self- efficacy.

Table 1

Comparison of advantages of direct observation, audiocasting and videocasting.

\begin{tabular}{l|c|c|c}
\cline { 2 - 3 } ADVANTAGE & DIRECT OBSERVATION & AUDIOCASTING & VIDEOCASTING \\
\hline real-time mode & + & + & + \\
\hline time-delayed display & - & + & + \\
\hline $\begin{array}{l}\text { independence of time and room } \\
\text { availability of the parts for re- } \\
\text { use }\end{array}$ & - & + & + \\
\hline $\begin{array}{l}\text { interactive circumstance } \\
\text { availability for the educational } \\
\text { analysis }\end{array}$ & + & + & + \\
\hline $\begin{array}{l}\text { availability for extracting the } \\
\text { necessary content }\end{array}$ & + & + & + \\
\hline $\begin{array}{l}\text { absence of interrupting the } \\
\text { presenter } \\
\text { function of detailed and diverse } \\
\text { analysis and consideration }\end{array}$ & - & + & + \\
\cline { 2 - 4 }
\end{tabular}




\section{Conclusion.}

In the ICT context pre-service teachers study the teaching-learning process via podcasts. The same is applicable for experienced teachers using integration of podcasts as a tool for self-development and the experience exchange. A lot of researches show that most pre-service teachers while their practice are unready for direct communication with their students despite the extended theoretical preparation and the good level of acquired professional knowledge and skills. In this case studying the authentic methodological casts after class and their analysis in class allows avoiding such unreadiness. Recording the pre-service teachers' practical classes allows increasing the level of selfreflection and mutual analysis if the applied techniques really work. This all influences also the self-efficacy feeling which influences the individual choice of language teaching techniques and educational tools while facing obstacles and sudden failures. The stronger the self-efficacy feeling is, the more likely the student is able to apply teaching strategies, methods and innovations and the more successful his/her practice is going to be.

\section{References:}

1. Astafurova TN, Olyanich AV (2011) Model' obuchenija studentov inojazychnoj virtual'noj kommunikacii v seti Internet. Prioritety razvitija klassicheskogo universiteta $\mathrm{v}$ uslovijah modernizacii obrazovanija. Volgograd: Volgograd state university, pp. $49-54$.

2. Balatska OL (2014) Pragmatic types of critical remarks in English-language research articles in Linguistics and Psychology: a comparative study. Literatura i kulturoznawstwo: osiągnięć, projekty hipotezę, 29.12.2014-30.12.2014. Warszawa: Wydawca: Sp. z o.o., «Diamond trading tour», pp. 113-115.

3. Constantine P (2007) Podcasts: another source for listening input. The Internet TESL Journal, № $13, \quad$ Available: http://iteslj.org/Techniques/ConstantinePodcastListening.html (Accessed: 23.08.10).

4. Gonzalez D (2003) Teaching and learning through chat: taxonomy of educational chat for EFL/ESL. Teaching English with technology, No.4, pp.33-45.

5. Malushko EY (2011) Innovative internet resources in teaching foreign languages. Linguistik und Frendsprachendidaktik im Dialog zwischen den Kulturen. Kirsch-Verlag, pp. $187-193$.
6. McMinn S (2007) Podcasting possibilities: increasing time and motivation in the language learning classroom. Available: http://www.eife1.org/publications/proceedings/ilf08/contributio ns/improving-quality-of-learning-withtechnologies/McMinn.pdf (Accessed: 01.03.2013).

7. Akbarova SN, Aymetova KD (2014) STUDYING THE ABILITIES TO NATURAL AND EXACT SCIENCES OF LYCEUM'S PUPILS OF TASHKENT CITY. ISJ Theoretical \& Applied Science 11 (19): 27-29. doi:

http://dx.doi.org/10.15863/TAS.2014.11.19.6

8. Seago N (2004) Using video as an object of inquiry for mathematics teaching and learning. Using video in teacher education. NY: Elsevier Science, pp. $259-286$.

9. Sherin MG (2004) New perspectives on the role of video in teacher education. Using video in teacher education. NY: Elsevier Science, pp. 1 $-27$.

10. Stanley G (2010) Blogging for ELT. British Council, Barcelona, Available: http://www.teachingenglish.org.uk/think/resour ces/blogging.shtml (Accessed:23.08.10). 